\title{
顔料工業界の展望亡のその技術的動向
}

\author{
中 村 隆 寿*
}

Prospect of the Pigment Industry and its Technicel Trends

Takahisa Nakamura

最近世人の色彩火対する関心が非常に高まってきた。 巷の雑誌一つを手《取って見ても，店頭の飾空を誢いて も亦婦人の服飾の様子を見ても直くにそれを感ぜしめら れる。この色を与光るものは申すまでもなく染料, 顔料 である。顔料はすでねわれわれの生活環境の中に溶け込 んでいてきわめて密接不離の間柄にあり，今日の各種製 品は顔料なくしてはなり立たないと言ってもよい位であ る。

しかるに一般の顔料関する認識はきわめて薄く，ほ とんど無関心であり, 顔料技術者も他の部門に比しきわ めて少ない。だがわれわれの日常生活に重要であること は否むことはできない。

有機合成化学と扣いてこの問題を取り上けられたのも そこらに意図が存するであろうと推察される。切角のご 依頼であるので叙上の意味飞打いて菲才をむ省みず，な えらかの拓役にも立つべしと拙文を草する所以である。 ご叱正を得ば幸とするところである。

\section{I. 業界の展望}

顔料の製造業者は決して少なくはない。とりわけ無機 碩料の業者は多く，しかも近畿以西にかたより，その分 布の状況は表 1 の如くであり, 有機顔料の事業者は割 合飞少い。

表 1 顔料製造業者の分布

\begin{tabular}{|c|c|c|c|c|c|c|}
\hline & & & & 中部以東 & 近畿以西 & 計 \\
\hline 無 & 機 & 顔 & 料 & 18 & 27 & 45 \\
\hline 有 & 機 & 顔 & 料 & 6 & 5 & 11 \\
\hline 合 & & & 計 & 24 & 32 & 56 \\
\hline
\end{tabular}

顔料の生䃥は年々順調なる伸長を示し，5ヶ年間に約 2 倍住し 他の産業とほほ同様なる歩調をたどってい 合。その明緗は 表 2,3飞示す如くである。

*東洋タンキ整造（株）(東京都中央区京橋 $2 丁$ 丁 6 ）

\section{II. 願料技術の動向}

顔料は使用時には粒子の状態てて用いられ，その柆子 の状況, 色度, 阷蔽力, その他の耐性が作業, 製品価值 飞大きな影響を及ほすのである。無機顔料においてもこ れらの問題とつき解決すべき点が多く残されているが， 今日の顔料技術は主として有機顔料に向けられて括り， より高度の技術が要請せられているのである。以下有機 顖料の分野につき最近の動向を述べるととする。

印刷インキ, 塗料, 顔料撩染郕などの中での顔料粒子 の大きさは $0.1 \sim 10 \mu$ であり，有機顔料 1 分子の大き さは $10 \sim 20 \AA$ であるから，1個の粒子は $10^{2} \sim 10^{4}$ 個 の分子からなっている。それ故色相, 濃度, 耐光性, 而 溶剂性, 财油量等の顔料的性質は化学構造ばかりでなく 粒子の大きさ, 分布, 形, 結晶形, 表面状態等飞も影郘 されるので, 有機顔料の生産管理の研究には粒子, 結晶 形態等飞つき考慮せられねはならぬ。理論的解明は きわめて困難であって，今日個々の顔料について経跧か ら概念的飞推察されていると過ぎない。たとえばある条 件で作られたスルホン化銅フタロシアニン染料とそのレ 一キの色特性值は 表4 の如く主波長，純度はほとんど同 じであるが, 明度を異にするためにわれわれの感覚とし てはかなり鮮明さに差異を感する。前者は水溶液として

表 4 スルホン化銅フタロシアニンスルホン酸 染料及びレーキの色特性值 (一例)

\begin{tabular}{l|c|c|c}
\hline & $\begin{array}{c}\text { 波 } \\
(\mathrm{m} \mu)\end{array}$ & $\begin{array}{c}\text { 純度(Pe) } \\
(\%)\end{array}$ & $\begin{array}{c}\text { 明 度 }(\mathrm{r}) \\
(\%)\end{array}$ \\
\hline 染料水溶液 $(\mathrm{pH}=7.5)$ & 484.3 & 61.0 & 42.3 \\
同上レーキ & 484.5 & 61.0 & 25.0 \\
\hline
\end{tabular}

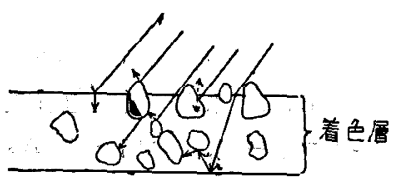

図 1 
表 2 無機顔料生夝䈏要表

(単位 $t$ )

\begin{tabular}{|c|c|c|c|c|c|c|c|c|c|c|c|c|}
\hline \multirow{2}{*}{ 品 } & & \multicolumn{2}{|c|}{ 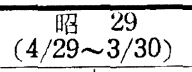 } & \multicolumn{2}{|c|}{$\begin{array}{c}\text { 照 } 30 \\
(4 / 30 \sim 3 / 31) \\
\end{array}$} & \multicolumn{2}{|c|}{ 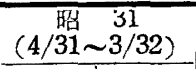 } & \multicolumn{2}{|c|}{$\begin{array}{c}\text { 嵒 } 32 \\
(4 / 32 \sim 3 / 33)\end{array}$} & \multicolumn{2}{|c|}{ 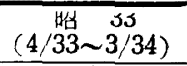 } \\
\hline & & & 生 産 & 需 要 & 生 産 & 需要 & 生 産 & 需 要 & 生産 & 需 要 & 生 産 & 蓝 要 \\
\hline 亜 & \multicolumn{2}{|l|}{ 華 } & 4,139 & 11,283 & 13,695 & 11,127 & 19,567 & 14,250 & 24,156 & 17,911 & 26,255 & 16,911 \\
\hline 鉛 & \multicolumn{2}{|l|}{ 丹 } & 2,552 & 2,880 & 2,687 & 2,561 & 3,220 & 3,131 & 3,627 & 3,204 & 3,621 & 3,498 \\
\hline 鉛 & \multicolumn{2}{|l|}{ 白 } & 836 & 753 & 819 & 811 & 971 & 956 & 1,196 & 1,101 & 1,036 & 1,018 \\
\hline サ & \multicolumn{2}{|l|}{$\ddot{~}$} & 2,849 & $2,80.4$ & 2,975 & 2,785 & 4,163 & 4,110 & 3,708 & 3,314 & 5,004 & 4,659 \\
\hline リ & \multicolumn{2}{|l|}{ 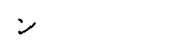 } & 3,579 & 3,272 & 3,198 & \multirow[t]{3}{*}{3,109} & 4,067 & 4,192 & 3,794 & 3,513 & 3,149 & 3,298 \\
\hline \multirow{2}{*}{\multicolumn{3}{|c|}{$\begin{array}{r}\text { 酸 化チタン（アナターゼ型） } \\
\text { " }\end{array}$}} & \multirow{4}{*}{9,606} & \multirow{4}{*}{9,378} & \multirow{4}{*}{17,292} & & 15,876 & 15,660 & 20,507 & 19,492 & 20,594 & 20,876 \\
\hline & & & & & & & 7,047 & 6,686 & 10,049 & 9,093 & 9,870 & 10,064 \\
\hline " & & & & & & 17,405 & 22,923 & 22,346 & 30,556 & 28,586 & 30,464 & 30,940 \\
\hline \multicolumn{3}{|c|}{ 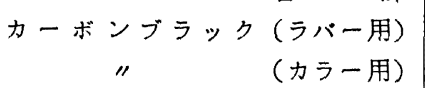 } & & & & & $\begin{array}{l}9,757 \\
1,440\end{array}$ & $\begin{array}{r}10,023 \\
1,327\end{array}$ & $\begin{array}{r}12,353 \\
1,490\end{array}$ & $\begin{array}{r}11,769 \\
1,494\end{array}$ & $\begin{array}{r}12,922 \\
1,413\end{array}$ & 13,159 \\
\hline \multicolumn{2}{|c|}{ カーボンブラック 合 } & 計 & \multirow{2}{*}{$\begin{array}{l}7,252 \\
3,888\end{array}$} & 7,118 & 7,780 & 7,905 & 11,19 & $|11,350|$ & 13,843 & 13,263 & 14,335 & 14,647 \\
\hline 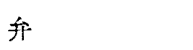 & \multicolumn{2}{|l|}{ 柄 } & & 3,799 & 4,019 & 3,996 & 4,916 & 4,924 & 5,857 & 5,796 & 5,983 & 6,012 \\
\hline 紺 & \multicolumn{2}{|l|}{ 青 } & 940 & 884 & 968 & 997 & 1,111 & 1,110 & 1,083 & 1,049 & 1,158 & 1,135 \\
\hline 群 & \multicolumn{2}{|l|}{ 青 } & 158 & 153 & 200 & 199 & 258 & 239 & 275 & 248 & 270 & 288. \\
\hline 黄 & \multicolumn{2}{|l|}{ 鉛 } & 2,648 & 2,383 & 1,169 & 2,953 & 3,993 & 3,753 & 6,267 & 4,039 & 3,889 & 3,710 \\
\hline 染 色 $v-$ & キ & & 709 & 434 & 749 & 508 & 809 & 568 & 848 & 576 & 755 & 578 \\
\hline モリブ デ & & & 207 & 206 & 236 & 237 & 302 & 299 & 351 & 348 & 373 & 366 \\
\hline シンククロメ & & & 106 & 106 & 147 & 146 & 227 & 223 & 325 & 323 & 338 & 337 \\
\hline 硼 酸 マン & ン & & 65 & 63 & 97 & 95 & 94 & 97 & 145 & 144 & 162 & 161 \\
\hline 酸 & 鉛 & & 208 & 209 & 272 & 269 & 335 & 334 & 435 & 432 & 389 & 383 \\
\hline 合 & & i) & 49,742 & 45,125 & 56,303 & 55,103 & 78,153 & 71,882 & 98,466 & 85,847 & 91,181 & 87,941 \\
\hline & & & 100 & & 112 & & 156 & & 196 & & 182 & \\
\hline
\end{tabular}

の色特性值であるに反して，後者は粒子としてのそれで あるから入射光線の反射吸収透過等が複雑になり（図 1 参照) 吾人の眼に入る反射光には種々の散乱光を含み, 拡散反射しかつ入射光のうちで着色層に吸収される量が 多いのて鮮明さの低い色として感ずる。

近年顔料捺染，プラスチック着色等の発展にとむない 耐光性, 耐溶剤性, 而熱性, 分散性等の顔料的性質の優 れた高級顔料が要望され，スレン系，ジオサシジ系， キナクリドン系顔料がしだいに使用されるようとなっ た。本交的いては（1）不溶性アゾ顔料，（2）アゾレ 一キ, (3) フタロシアニン類, (4) シオキサジン, キナ クリドン系，(5) スレン系について最近の傾向を照介す る。

1. 不溶性アソ顔料不溶性アゾ顔料とは $-\mathrm{SO}_{3} \mathrm{H}$ や- $\mathrm{COOH}$ 等の水可溶性基を有しないアゾ色素でいわ ゆる “Pigment Dyes” 飞属する。工業的飞はカッナ ラーとして $\beta$-ナフトール, ナフトール As 類, アセト ・アリリドンフェニルメチルピラゾロン類を用いたもの ろ゙重要である。

同一化学構造飞てもカップリング条件や後処理の方法
とよって異なった顔料的性實を有するものが得られる。 その原因は水素結合形成による構造上の変化任基因する 場合 ${ }^{13)}$ や粒の大きさ，分布の相異による場合 ${ }^{47)}$ 或は 結晶形態の相異飞よる場合 ${ }^{8)}$ 等がある。

カップリング条件はジアゾ化物の安定度, カップリン グ速度等を考虑して決定されなければならないが1)，カ ップリング後ピグメンスラリーを加熱することによって

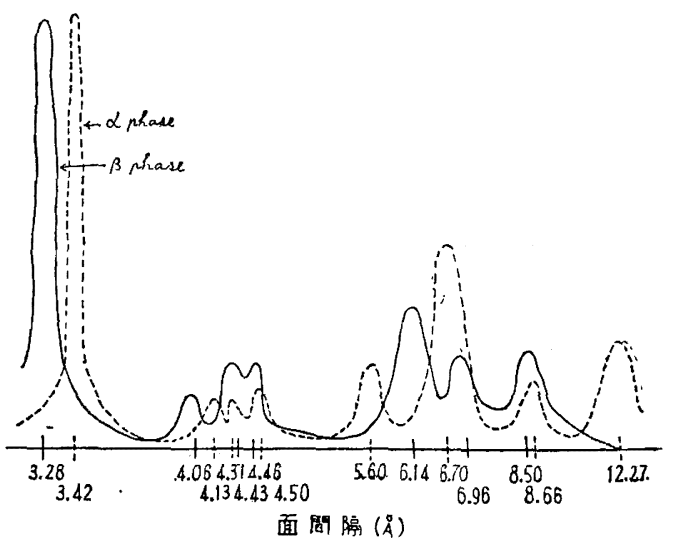

因 2 結晶転移図 


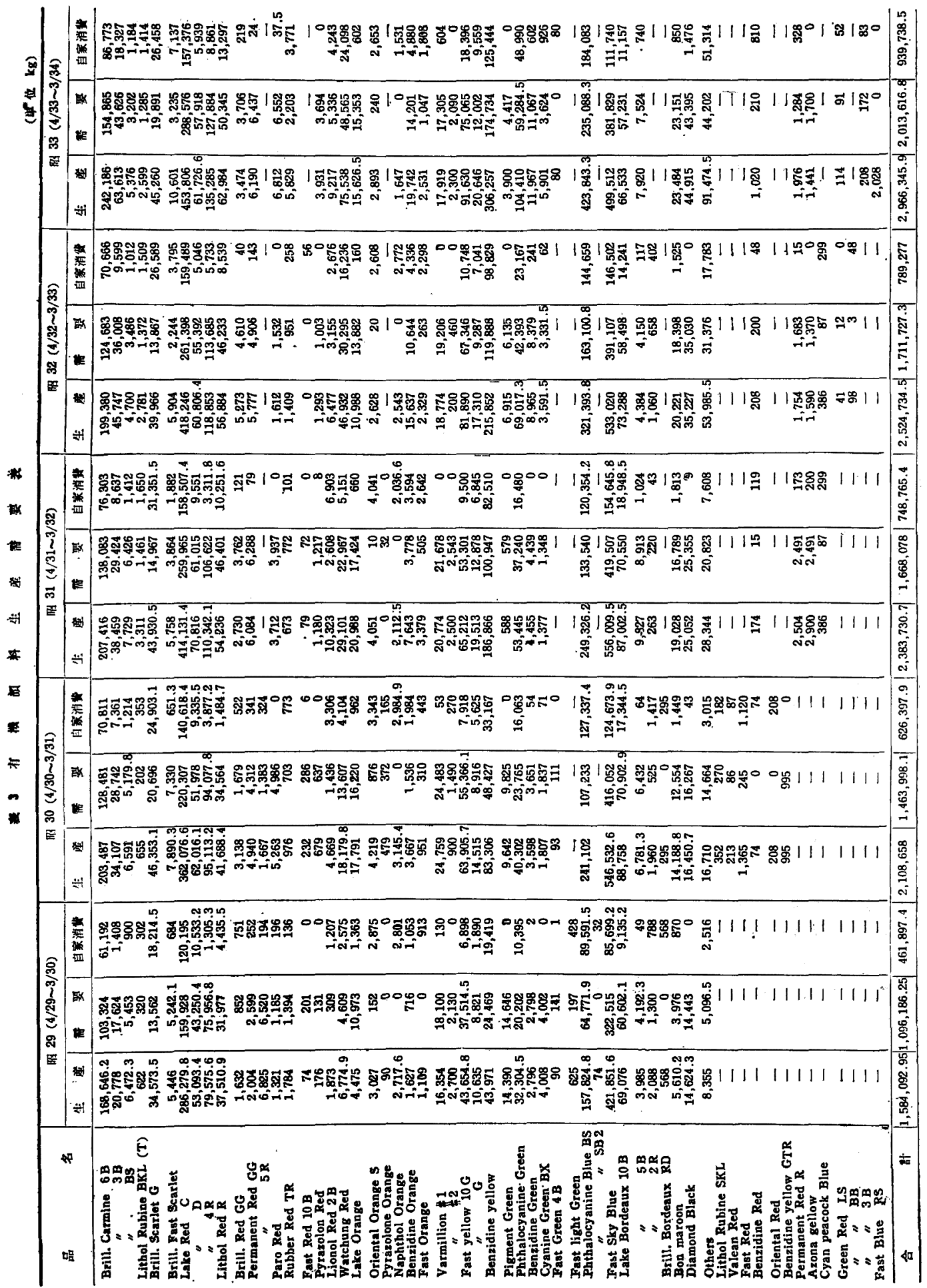


いちじるしい色相の変化が起る場合5) とそれはど変化し ない婸合(1 とがある。Pratt はクラスター説によってこ の変化を模型的飞説明している”。

結晶形態の変化はたと艺ばフストレット3GL ベー スとナフトール AS-OL とをカップリングして得られ る顔料（1）はクロロホルム，トリクロルベンゼン，テ トラクロルエタン, アセトン等の溶郕飞て処理すると 图 2 飞示す如く $\beta$-phase 飞転移し, 耐光性, ベヒク ルとの湿潤性が向上するという

G Bleisch はパーマネントレット $4 \mathrm{R}$ (2) パーマネ ントレット $2 \mathrm{R}(3)$, ハンザエロー G (4) などをクロロ ホルム溶液より注意深く結晶せしめ, その結晶の天然色 顥微鏡写真を摄影している ${ }^{10) 。 ~}$

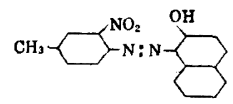

(2)

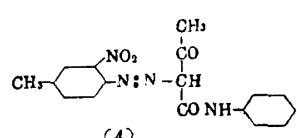

(4)

顔料はその製造法により顔料的性質が異なってくるの でいろいろの処理がほどこされ用途に適応した性梖が付 与せられる。最近の有機顔料の傾向はかかる用途適性付 与のための研究が盛んである。たとえばベンシジンレッ ドの製造時に扮いてオイルエマルションの添加11) やカ ップリングを事実上無水の状態ではけしく混合かくはん して行いきわめて微細な粒子を作ること融 が提案され ている。

また一方耐光性, 耐薬品性, 耐熱性等の改良飞ついて の化学構造上ょりの研究も最近特飞活潑である。就中べ ンシジンエローやナフトールカラーの耐光性, 耐溶剤性 の改良に対する報告が多い。

ベンシシシンエローやナフトールカラーは有機溶剂飞対 してブリードしやすいという不溶性ア・゙顔料としての共 通の欠点があるためにポり㙁化ビニールその他のプラス チックの着色剤として使用するために大きな障害となっ ている。これら顔料の研究改良法関する傾向を 表 5 飞示す。

ベンシシシンエロー 類は 耐光珄向上のためにアセトア セトアニライドのベンゼン核の $-2, \sim 4$ 位を $-\mathrm{OCH}_{3}$, $-\mathrm{OC}_{2} \mathrm{H}_{5}$ で置換する方法 ${ }^{13}$ (No. 3, 4) やベーズにさら 飞Cl を尊入すること ${ }^{14)}$ 亿よる方法が試みられて挌り， 耐溶剂性改良飞ついては 4 位 $\mathrm{K}-\mathrm{Cl},-\mathrm{NHCOCH}_{3}$ (No. 3), ${ }_{7} \mathrm{NHCO} \longrightarrow(\mathrm{No} .5)$ を導入するととにより， たベース類は 3,3'-ジクロルベンシシシンとかわり，

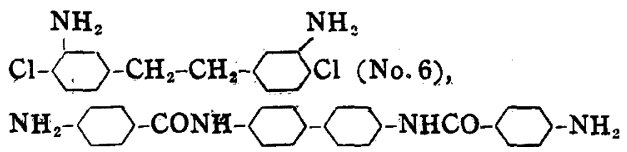

（No.2）を用いることKよって達せられるという。

この系統属する商品としてクロモフター心 ガライト ${ }^{16)}$, パーマネントエロー HR (5) ${ }^{17)}$ がある。

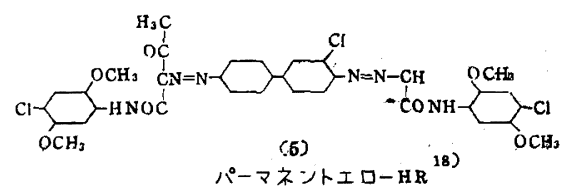

ナフトールカラーとついては，フッ素含有のある種の ものは耐光性が優れていることが報告されて和り ${ }^{19}$, 耐溶剤性の改良飞はベンシシシンエローの場合と同様 -NHCO- 基の導入が試みられている（No. 9,10,11,12, 13)。

2. アゾレーキ アゾレーキとは $-\mathrm{SO}_{3} \mathrm{H},-\mathrm{COOH}$ 等の水溶性基を有するアゾ色素をカルシウム，バリウ ム, マンガン, コバルト等の水溶性塩頪て水に不溶性と して(この操作をレーキ化という) 得られる顔料であ る。

アゾレーキはレーキ化によって結合する金属の量, 金 属の結合状態等の化学的要因が複雑であり, 均一な製品 を得ることは困難である。ア・゙色素には水汇完全溶解 するものと難溶性のものとがある。前诸は後者化此較す ると, 色素の物理的原因によるレーキ化の複雑さは少な いだけに各ロット間の変動は割合に少ないが，後者は色 素自体の結晶形態, 粒子形態等がレーキ化後の顔料の性 質にまで影響を及ほすから顔料の合成条件の検討や製造 に淤けるロット間の変動を探求するためには, 色素の合 成条件, さらにシアゾ化の条件まで関連性を見出され ばならない。この種のものと属する代表的な顔料はレー キレット C (6), ウォッチャングレッド(7) 等である。

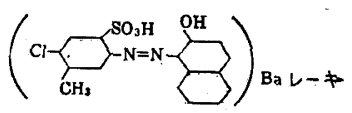

(6)

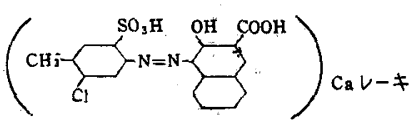

(7)

たとえばレーキレッド C の色素は C 酸のジアゾ化, $\beta$ ナフトールとのカップリング条件によって図 3-1,-2 に見られるような結晶形態のちがいがあり、これらから 作られたレーキもまた 図 4-1,-2 亿みられるごとく粒

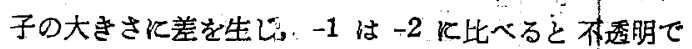
マストーンは黄味である ${ }^{20 \% 。 ~}$ 
表 5 不溶性アアゾ顔料

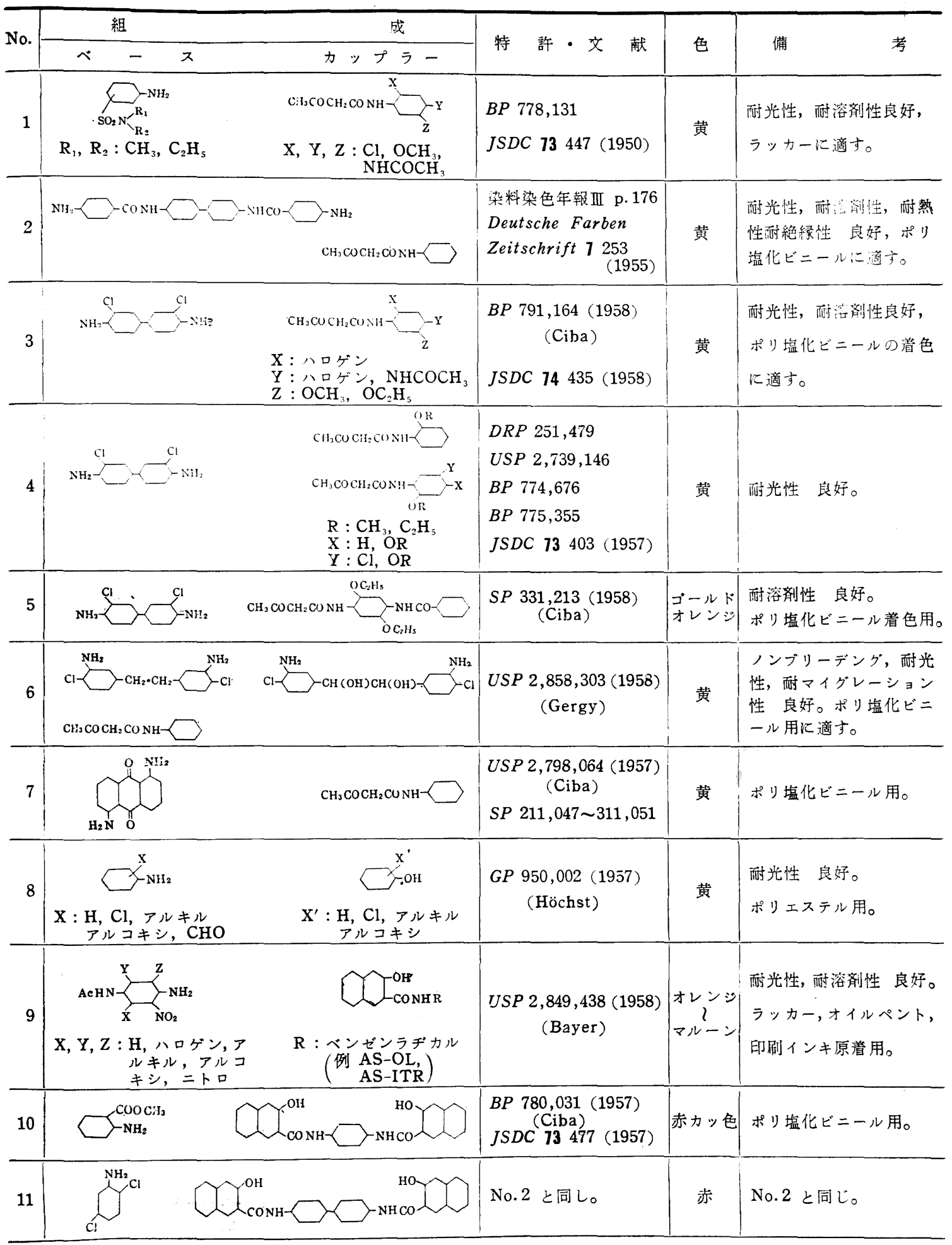




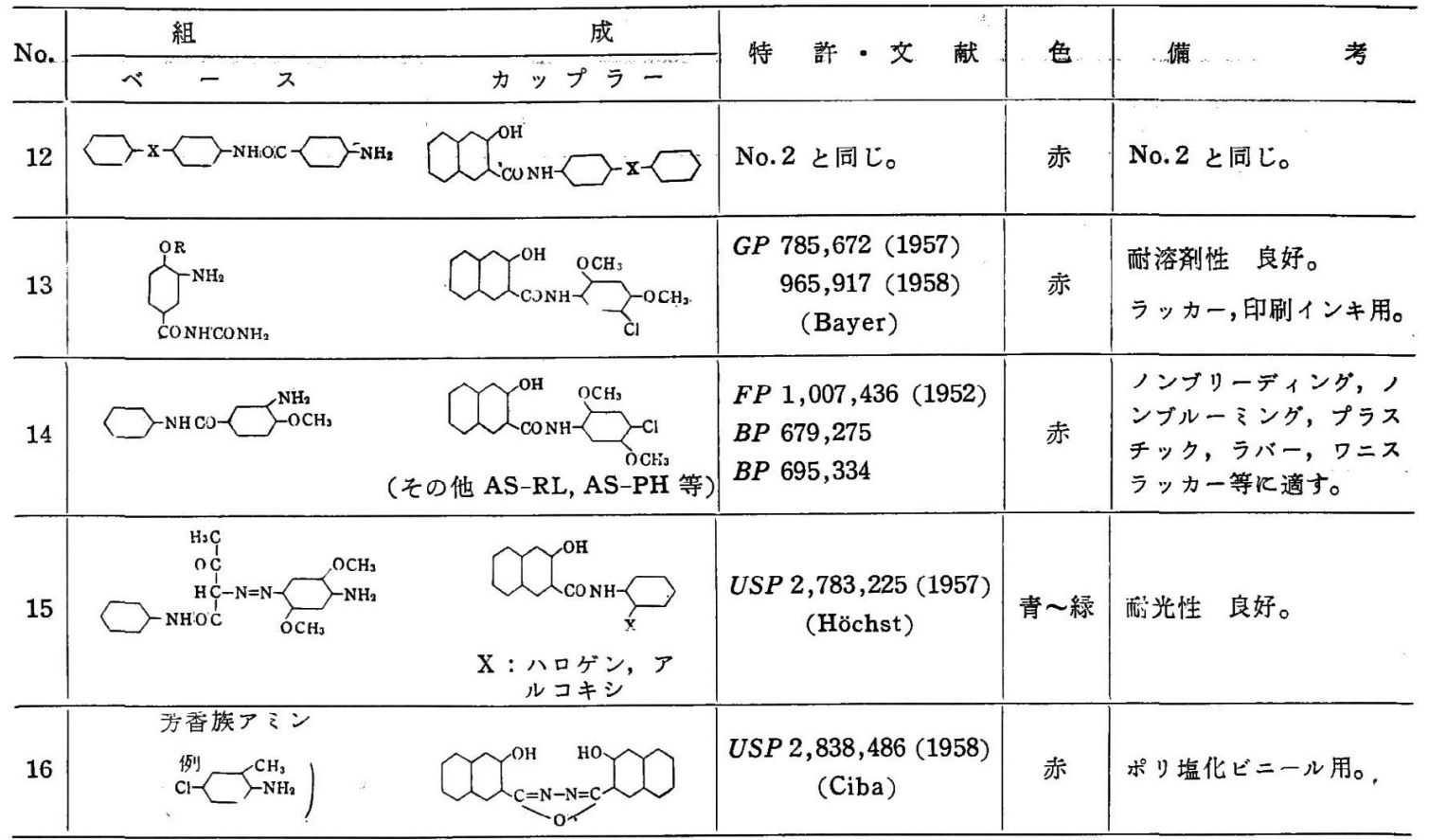

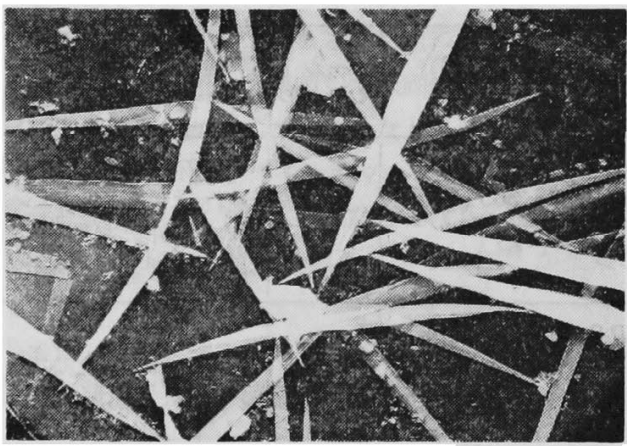

$-1$

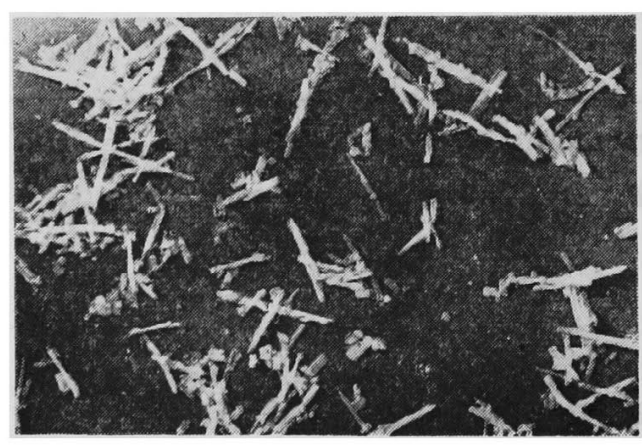

$-2$

図 3 レーキレッドC 染料 $(\times 20,000)$

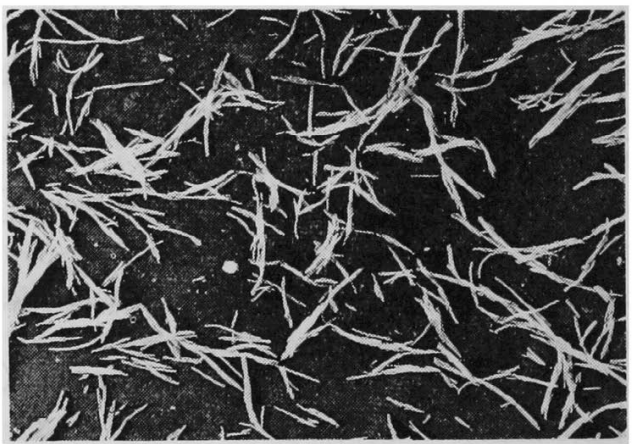

-1 (図 3-1 よりの顔料)

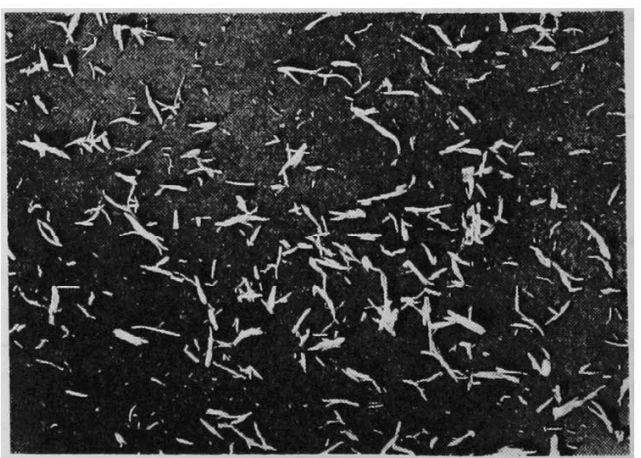

-2 (図 3-2 よりの顔料)

国 4 レーキレット $(\times 20,000)$ 


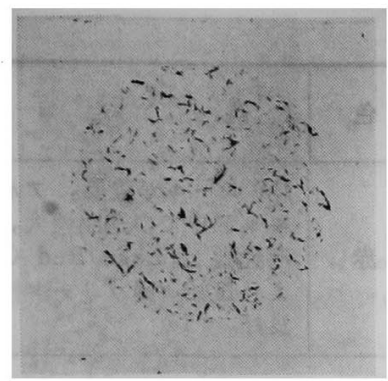

カップリング直後

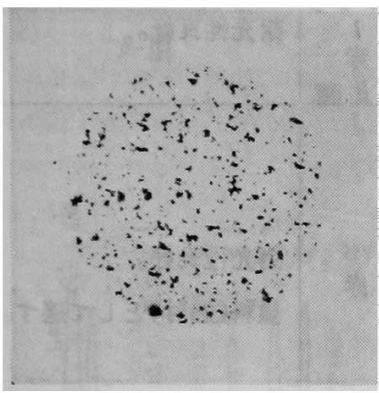

カップリング後 $64^{\circ} \mathrm{C}$ 飞加熱

カップリング後 $\mathrm{pH}=7$
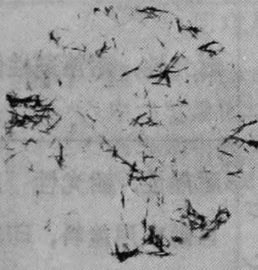

としたもの

図 5 ウオッチャングレッド染料

$(\times 117)$

表 6 ウオッチャングレッド色素の溶解度 ${ }^{23}$

\begin{tabular}{|c|c|c|c|c|}
\hline No. & 坛料の状熊 & $20^{\circ} \mathrm{C}(\%)$ & $40^{\circ} \mathrm{C}(\%)$ & $70^{\circ} \mathrm{C}(\%)$ \\
\hline 1 & $\begin{array}{l}\text { カップリング } \\
\text { 後加熱せず }\end{array}$ & $\begin{array}{l}\mathrm{pH}=8.6 \\
0.69 \text { (針) }\end{array}$ & $\begin{array}{l}\mathrm{pH}=8.6 \\
1.06 \text { (針· } \\
\text { 粒) }\end{array}$ & 0.43 (粒) \\
\hline 2 & $\begin{array}{l}\text { カップリンク゚ } \\
\text { 後 } \mathrm{pH}=7,72 \cdots \\
64^{\circ} \mathrm{C} \mathrm{K} \text { 加熱 }\end{array}$ & 0.19 (粒) & & 0.45 (柆) \\
\hline 3 & $\begin{array}{l}\text { カップリング } \\
\text { 後加熱せすす } \\
\text { pH=7.0 K調 } \\
\text { 節 }\end{array}$ & 0.13 (針) & & 0.30 (釬) \\
\hline 4 & $\begin{array}{l}\text { No. } 3 \text { を } \mathrm{pH}= \\
10.2 \text { とし 加 } \\
\text { 熱 }\end{array}$ & & 0.52 (粒) & \\
\hline
\end{tabular}

またウォッチャングレッドの色素はカップリング条 件, カップリング後の加熱の有無, $\mathrm{pH}$ の変化によって 表 6, 図 5 に示したごとく溶解度, 結晶形態のちがい ある ${ }^{21)} 。$
このように水難溶性色素のレーキ化については，その 条件によって顔料的性質の異なったものが得られる。

Pratt は顔料としての構造として Lake Red C, Lake Red D, Lake Red P 等飞対して おのおの (8)，(9), (10) の構造を推察している ${ }^{22)}$ 。

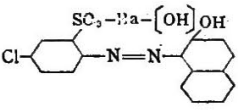

(8)

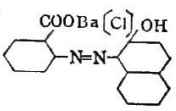

(9)
Sake Red C

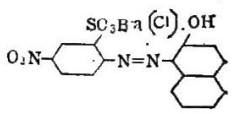

(10)

レーキ化金属は通常 $\mathrm{Ca}, \mathrm{Ba}, \mathrm{Sr}, \mathrm{Mn}, \mathrm{Co}, \mathrm{Ni}$ 等が 使われるが，Zrレーキの顔料もある。たと只ば $\left[\longrightarrow-\mathrm{N}=\mathrm{N}-\longrightarrow \mathrm{SO}_{3}\right]_{2} \mathrm{Zr}_{5} \mathrm{O}_{9}$ は着色力が大で(4) $\mathrm{Zr}$

塩による塩基性染料, 酸性染料のレーキ化が報告されて いる ${ }^{25,26)} 。$

最近のアゾレーキの傾向は 表 1 亿示した如く，C酸 の - $\mathrm{CH}_{3}$ 基を-シ $\mathrm{C}_{3} \mathrm{H}_{7}$ 基沉かえて耐光性を改良する 試み (No.17) やジクロル体による耐光性向上をはかっ ている(No.18)。特飞興味あるは AS 類をカップラー としジスルホン類，C酸扔よびその異性体等をジゾ成 分とする染料を $\mathrm{Ca}, \mathrm{Sr}, \mathrm{Mn}$ 等のレーキとし耐光性の すぐれたものを得ようとしていることである（No. 19， 20)。

従来使用されているアミン類にはシクロル体, ジスル ホン酸体はほとんどなかったが最近積極的に取り上げら れているのは注目すべきである。

その他クロム錯塩を作った後 Mn レ一キとする（No. 23) ことや, よく知られている Green gold ${ }^{27,28)}$ 扣よ びその同属体の金属錯塩アゾレーキは今後進展する可能 性がある。

\section{3. フタロシアニン顔料}

i. 搆造, 結晶形態 銅フタロシアニンの構造は Robertson 29-32) らのX 線解析による研究から原子間距離 が明らかとなった。Kendall ${ }^{33)}$ とよれば $\alpha$-型と $\beta$-型37 の赤外吸収スペクトルのいちじるしい差異は $\propto$-型で $730 \mathrm{~cm}^{-1}$ の吸收帯が $\beta$-型で $720 \mathrm{~cm}^{-1}$ 飞対応すること で， $\boldsymbol{\alpha}$-型と $\beta$-型の結晶構造の差は結晶面内で分子配列 が異なり，スペクトルの差は分子間力が相互に異なるこ ととよるとして説明している。

その分子配列は 図 6 に示す如く $\beta$-型の分子配列か ら $\alpha$-型の分子配列飞転移するには $5 \dot{A}$ の移動と $25^{\circ}$ の 回転が必要でおると述べている゙ ${ }^{34-36) 。 ~}$

メタルフリーフタロシアニンK $\alpha-\beta-$ および $\gamma$-型 
表 7 ア ゾ レ ー キ

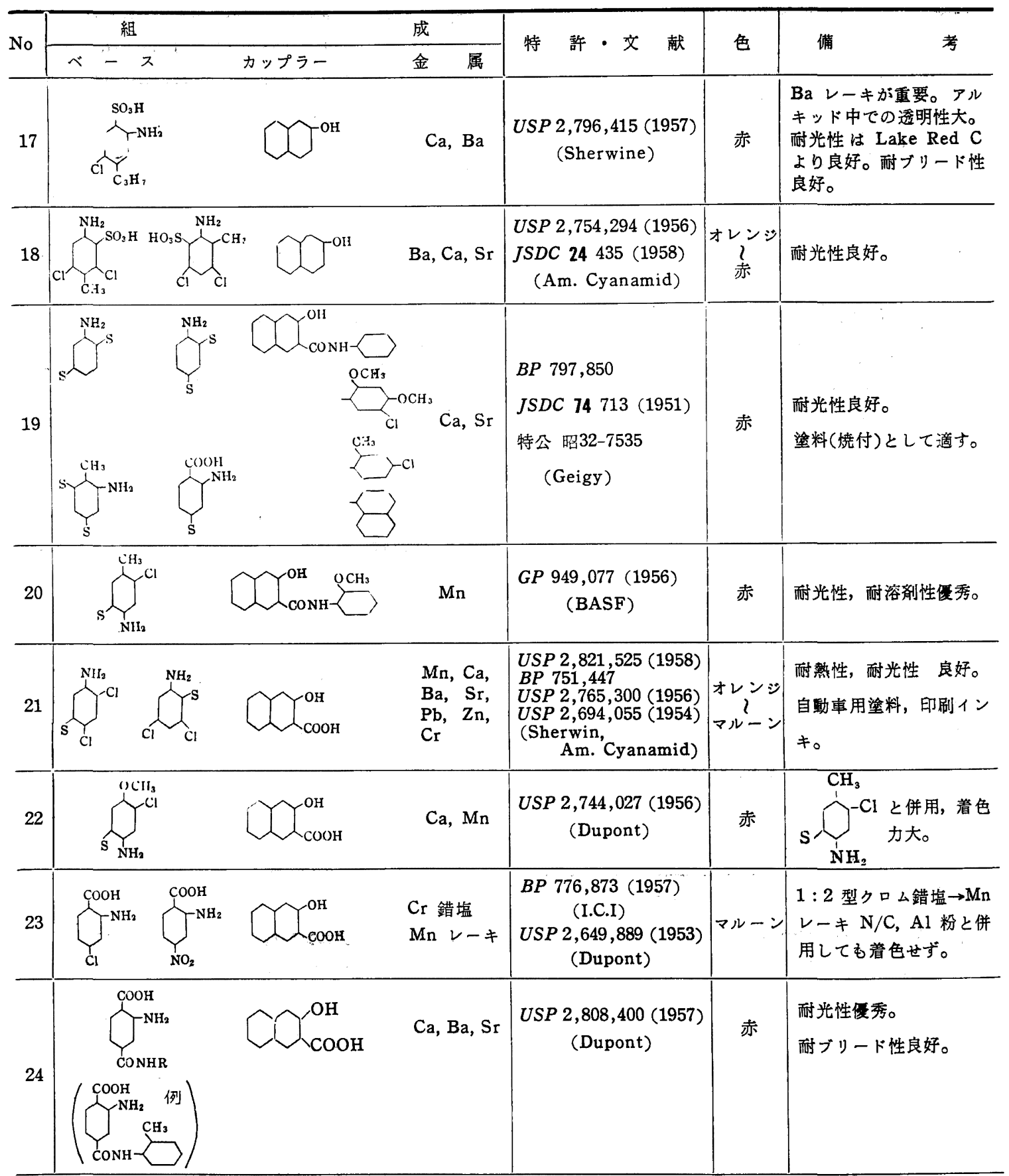

の結晶形態が知られている ${ }^{38)}$ が銅フタロシアニンにつ いても同様 $r$ - 変態が発表されている ${ }^{39) 。}$

無水フタール酸中で塩素化して得られる高塩素化銅ま たはメタルフリーフタロシアニンの Crude
型(1)で，これをアシッドペーステングすると $\beta$-型41) 転移する。

しかし $\beta$-型塩素化銅またはメダルフリーフタロシア ニンはトリクロロペンゼン中で煮沸してむ，銅フタロシ 


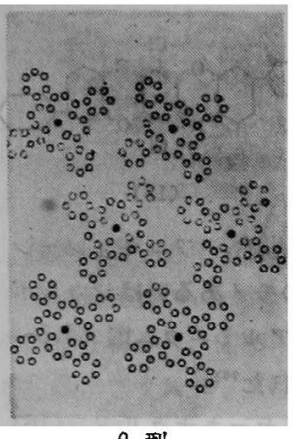

$\beta$-型

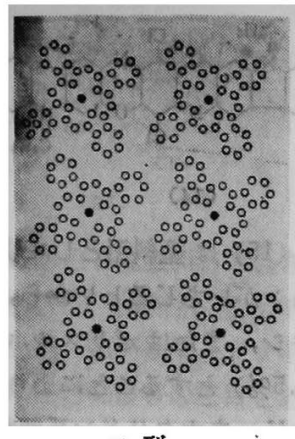

$\alpha$-型
図 6

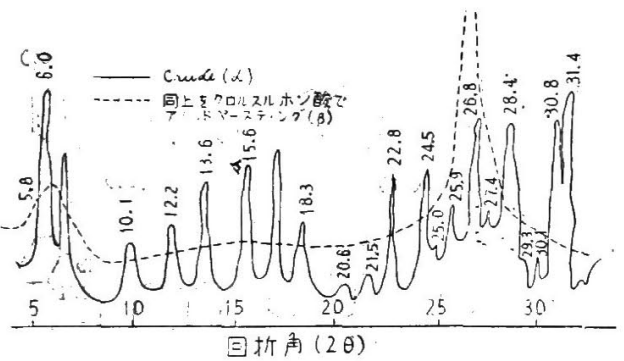

図 $t$ 鉰フタロシアニンを無水フタール酸 中で塭素化して得られた $(14.3 \mathrm{Cl})$ 高塩素化銅フタロシァニンのX 線回 折図 $(\mathrm{CuKd} / \mathrm{Ni})$

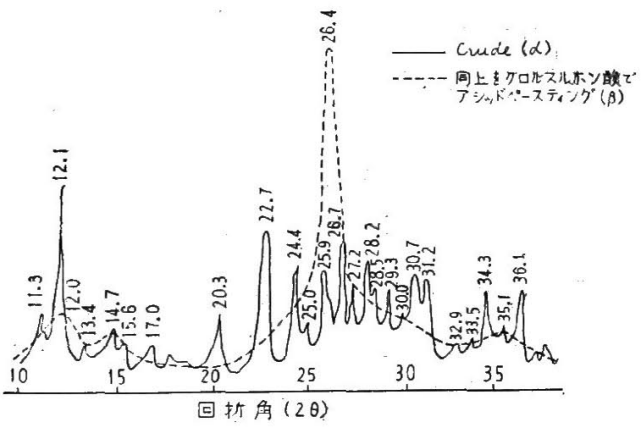

図8メタルフリーフタロシアニンを無水 フタノール酸中で塩素化して得られ た $(13.5 \mathrm{Cl})$ 高塩素化メタルフリー フタロシアニンのX X線回折図 $(\mathrm{CuKd} / \mathrm{Ni})$

アニンの $\beta$-型が $\alpha$-型に転移するごとく完全には $\alpha$-型 飞転移しない。

図 7 招よび図8 亿高素化銅括よびメタルフリーフ タロシアニンの $\mathrm{x}$ 線回析図在示す42)。

$\beta$-型銅フタ只シアニンはトルエン, . 未シンンの如き芳
香族有機溶剤中で $\alpha$-型飞転移し，着色力の低下，色相 の変化をもたらすために，いわゆる溶剤安定型銅フタロ シアニンの製造法に関して後述の如く種々の方法が考案 されているが最も一般的な方法は 4- または 5-クロル 銅フタロシアニンとよる改良法である。

3-クロル，4-メチル銅フタロシアニンは芳香族有機溶 剤中で結晶転移を起すが，4- または 5-クロル銅フタロ シアニンは $\mathrm{Cl}$ のイオン半径が分子間距離 (3.38 $\mathrm{A}) 飞$ 接近し容易に $3.38 \AA$ の距離をとりにくくなるためであ ると説明されている ${ }^{34)} 。$

ii. 銅フタロシアニン 銅フタロシアニンはトルエ ン，キシレンの如き芳香族有機溶剂を合有するべヒクル 中で結晶が成長し, 着色力の低下や色相の変化を起す欠 点拉よびこれらベヒクル中で顔料粒子が集合を起し色む ら，濃度低下等をきたす欠点がある。最近の銅つタロシ アニンに関する研究ははとんどこの欠点の改良に集中さ れている。

この欠点の改良のためにとられている方向は大体次の 5方法にわけられる。

(a) 銅フタロシアニンのベンゼン核の 4- または 5- の位置 $\left(\mathrm{Cl}^{43},-\mathrm{NO}_{2}{ }^{44)},-\mathrm{NH}_{2}{ }^{44)},-\mathrm{SO}_{3} \mathrm{H}^{43)}\right.$, $-\mathrm{COOH}^{45},-\mathrm{CONH}_{2}{ }^{45)},-\mathrm{P}(\mathrm{OH})_{2}{ }^{45}$ 等の置換基を導 入乙て非結晶性，非集合性とする方法。

i(b) 銅フタロシアニン $\mathrm{K} \mathrm{Sn}, \mathrm{Al}, \mathrm{Ti}, \mathrm{Mg}^{46,47\}}$ 等 のフタロシアニンを混合して非結晶性, 非集合性とす る方法。

(c) 銅フタロシアニンを安息香酸アルミ(4) 等でコ 一テングする方法。

（d）銅フタロシアニンを $\mathrm{AlCl}_{3}, \mathrm{TCB}$ 中で加熱し て非結晶性とする49)。あるいはメチルシクロヘキサン 中て銅フタロシアニンを生成し，65\% $\mathrm{H}_{2} \mathrm{SO}_{4}$ 中でア シッドペーステングすることによって，メチルシクロ ヘキサンを分子間に残存せしめ結晶転移の障害とする 方法等 $50 \%$ 。

（e） $\alpha$-型銅フタロシアニンを有機溶郕の存在下で ボールミーリングして $\propto$-型の顔料化を行う方法 ${ }^{51}$ 。

これらの方法のうち（e）は最む著名な方法であり， ついで (a) 法, 主としてクロル置換体 ${ }^{52)}$ が工業的飞作 られている。

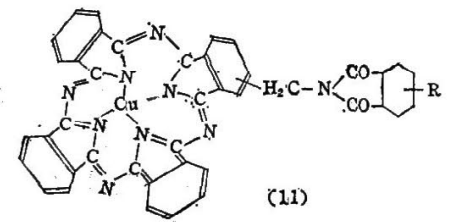


（a）法飞属するむのとしてフタルイミドメチル誘導 体 ${ }^{52 \sim 54)}$ は興味がある ((11) 参照)。

iii. フタロシアニングリーン 高塩素化銅フタロシ アニン, 高塩素化メタルフリーフタロシアニン ${ }^{55)}$, テト ラフェニルフタロシアニン56), フェネラックピリシン $Y^{57)}$ 等があるが高塩素化銅フタロシアニンが最む多く 生産されている。最近テトラクロルフタロジニトリルか らヘキサデカクロル銅フタロシアニンの製造が可能にな った ${ }^{58)}$ 。

iv. その他のフタロシアニン類 ビス（4-アミノフ エニル）アミン，フタロニトリル括よびナトリウムエチ ラートからオレンジ〜ブラウンのマクロ環フタロシアニ

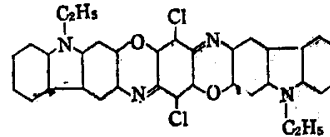

(14)

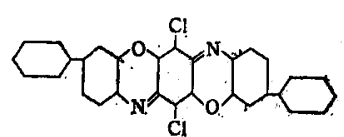

(15)

（15）は塗料用として使用した場合，フロキュレーシ ョンがいちじるしいから，これのモノあるいはシカルボ キシ，またはポりスルホン酸のアルミニウム塩 (3.5〜 2.5\%) とすることにより改良された ${ }^{66}$ 。

ii. キナクリドン系顔料 リニャーキナクリド(16) は 1921 年 Eckert, Seidel らとよりはじめて合成され た赤色物質 (16) で類似構造を有する (17)，(18)，(19） は黄色であることは興味深い。

ン型が得られ (12), 顔料捺染, ゴム, プラスチックの着： 色飞適寸とい弓 ${ }^{39)}$ 。

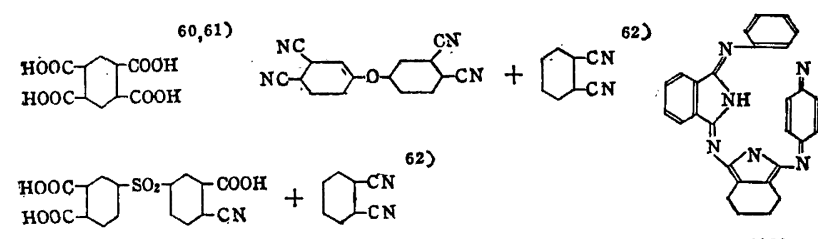

(12)<smiles>O=C1CC2NC3CCCCC3OC2CC1NC1CCCCC1</smiles>

(16)

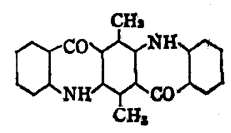

(18)

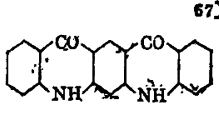

(īi)

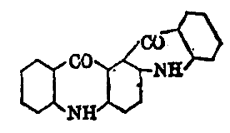

(19)
からそれぞれ対応するポリフタロシ アニン (ブルーグリーン〜グリニシ ニブラック) が得られる。

またテトラアザポルフィン $\left(13^{\prime}\right)$ 63,64) も興味がある。

4. ジオキサジンおよびキナクル ドン系顔料

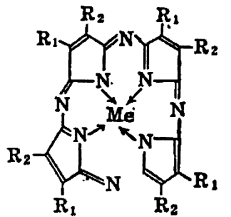

(13') i. ジオキサジン系顔料 ジオキサシンン類の最も簡単 な型と考えられる 6,13-シクロルートリフェノージオキサ ジン（13）はアニリンあるいは 0 アアニシジとクロラ 一ルから容易に得られる赤色物質である。

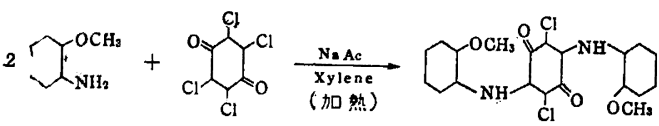

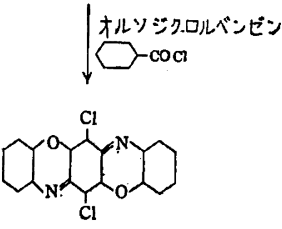

(13)

したがって種々の適当なアミン類を使用するととによ って多数の誘導体が得られるがその内でも (14) は耐光 性, 而溶刋性がすぐれビニル，塗料用として使用されて いる52,65) ことはよく知られている。
Eckert, Seidel らは 2,5-シァニリノテレフタール酸 (20)を $\mathrm{PCl}_{5}, \mathrm{AlCl}_{3}$ または $\mathrm{ZnCl}_{2}$ で閉環して(16)を 得た。

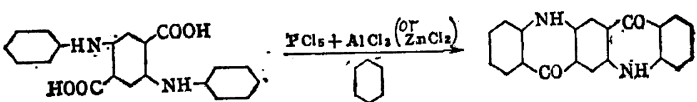

(20)

(16)
その後 Liebermann ${ }^{70)}$ は $(20)$ を嗍酸の存在下で $320 \sim 330^{\circ} \mathrm{C}$ 飞加熱して（16）を得た。

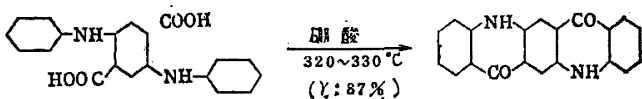

(16)
(20)

同時飞数種の誘導体例えば (21), (22)，(23), (24), (25)，(26) 等を合成した。

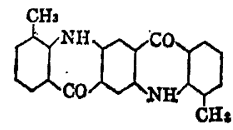

(21)

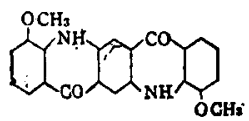

(23)<smiles>CC1CCC2NC3CC4OC5CC(C)CCC5OC4CC4C(C)CCC4NC3CC2C1</smiles>

(22)

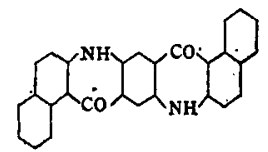

(2) 


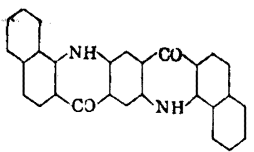

(25)

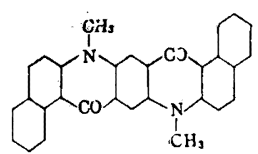

(26)
最近（21）の化学構造を有する赤色有機顔料が市販さ れるにおよび71) そのすぐれた耐光性, 耐熱性, 耐溶剤 性の諸性質から，印刷インキ，塗料，顔料挎染，ブリキ 板印刷, プラスチック等の用途飞色材関係者の注目をあ つめている。

Dupont 社の合成法 ${ }^{71,72)}$ はコ八ク酸ジェチルエステ ル $(27) \rightarrow(28) \rightarrow(29) \rightarrow(30)$ を連続的にダウサムA中て 行い(30) $\rightarrow$ (16) をアルコール, カセイソーダの存在下 でニトロベンゼン-m-スルホン酸ソーダで酸化するにあ る。

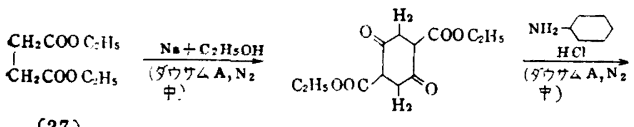

(28)

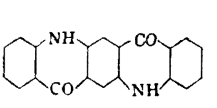

(16)

表 8 キナクリドン誘導体

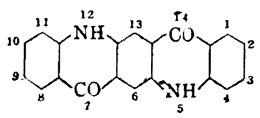

\begin{tabular}{|c|c|c|}
\hline 誘 & 体 & 色 \\
\hline $\begin{array}{l}3,10 \text {-dichloro-Quinacr } \\
2,9-\text { " " } \\
4,11 \text {-dimethyl- } \\
2,9 \text { " " } \\
2,9 \text {-dimethoxy }\end{array}$ & $\begin{array}{l}\text { idone } \\
\text { " } \\
\text { " } \\
\text { " }\end{array}$ & $\begin{array}{l}\text { Red } \\
\text { Red-violet } \\
\text { Yellow red } \\
\text { Red-violet } \\
\text { Red-violet }\end{array}$ \\
\hline $\begin{array}{l}3,4,10,11 \text {-tetrachloro } \\
1,3,8,10 \text { " } \\
2,4,9,11 \text {-tetrabromo } \\
2,3,9,10 \text { " } \\
1,4,8,11\end{array}$ & ", & $\begin{array}{l}\text { Orange-red } \\
\text { do } \\
\text { Orange } \\
\text { red } \\
\text { Orange }\end{array}$ \\
\hline $\begin{array}{l}2,4,9,11 \text {-tetrafluoro } \\
1,4,8,11 \text { " } \\
2,4,9,11 \text {-tetraiodo }\end{array}$ & "' & $\begin{array}{l}\text { do } \\
\text { do } \\
\text { do }\end{array}$ \\
\hline $\begin{array}{l}2,4,9,11 \text {-tetrachloro } \\
2,3,9,10 \text { " } \\
\text { (または } 1,2,8,9 \text { ) } \\
1,4,8,11 \text { " }\end{array}$ & " & $\begin{array}{l}\text { do } \\
\text { Yellow-red } \\
\text { do }\end{array}$ \\
\hline
\end{tabular}

また同様な合成法で 表 8 亿示す誘導体が 合成され $た^{(3,73)}$

（31）を濃硫酸で閉環すると黄色のアンギュラキナク リドン（32）を生成する ${ }^{70,75) 。 ~}$

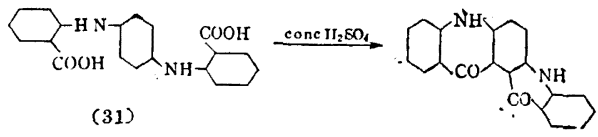

（32）のニトロ化合物 (33) は 黄色〜だいだい色である ${ }^{74}$ 。

リニヤーキナクリドンは同質 多像て $\alpha-, \beta-, \gamma-$ 変態加知 5

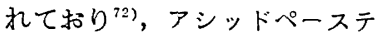

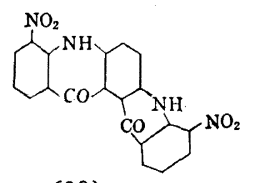

(33)
ング, Dry Salt milling Kよって $\alpha$-phase が得られ る。 $\alpha$-phase をシメチルホルムアミド中に浸漬するか，

少量の

少量のシメチルホルムアミト存在下で Salt-milling すると $r$-phase とな り, キシンンを使用して Salt milling を行うと $\beta$-phase となる。色は概し $\tau r$-phase は興味のある赤色で, $\beta-$ phase, $\alpha$-phase は青味のある赤色で ある。Cinquasia Violet $\mathrm{R} は \beta-$ phase K, Red Y, Red B は $\gamma$-phase そ属する。

5. スレン系䪹料 スレン系顔料 (30)

は構造的にはアントラキノン誘導体招 よびチオインジゴ誘導体がその大部分を占め，一般に耐 光性, 而熱性等がすぐれているが概して高価なため今ま ではあまり使用されなかったが最近顔料捺料, プラスチ ック類の着色に用いられるようになった。

チオインジゴ系のあのはチオインジゴ核に八ロゲン, アルキル基, アルコキシ基等の置換されたもので, 大体 赤紫系統の色相に限られているが，アントラキノン系の ものでは建染メ染料系顔料が主でそれらは青色，たいだ い色，赤色，黄色等のものが多い。

現在工業的江用いられている代表的な顔料をいくつか 揭げてみる。

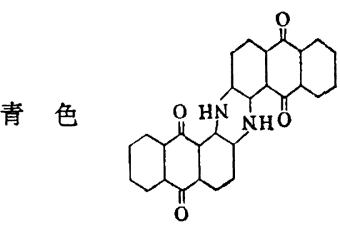

Indanthrene Blue RS (C. I. 69800 )

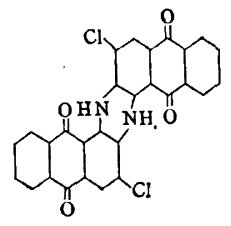

Indanthrene Blue BC 
赤色<smiles>CC1CC(Cl)C2C(=O)C(=C3SC4CC(Cl)CC(C)C4C3=O)SC12</smiles>

Indanthrene Red Violet RH

(C. I. 73385)

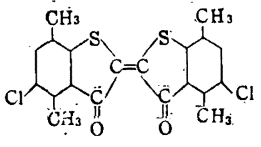

Indanthrene Red

Violet RRN

(C. I. 73395)

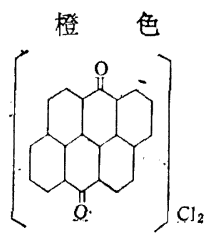

Indanthrene

Brilliant Orange GK

(C. I. 59305)

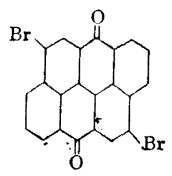

Indanthrene

Brilliant Orange RK

(C I 59300)

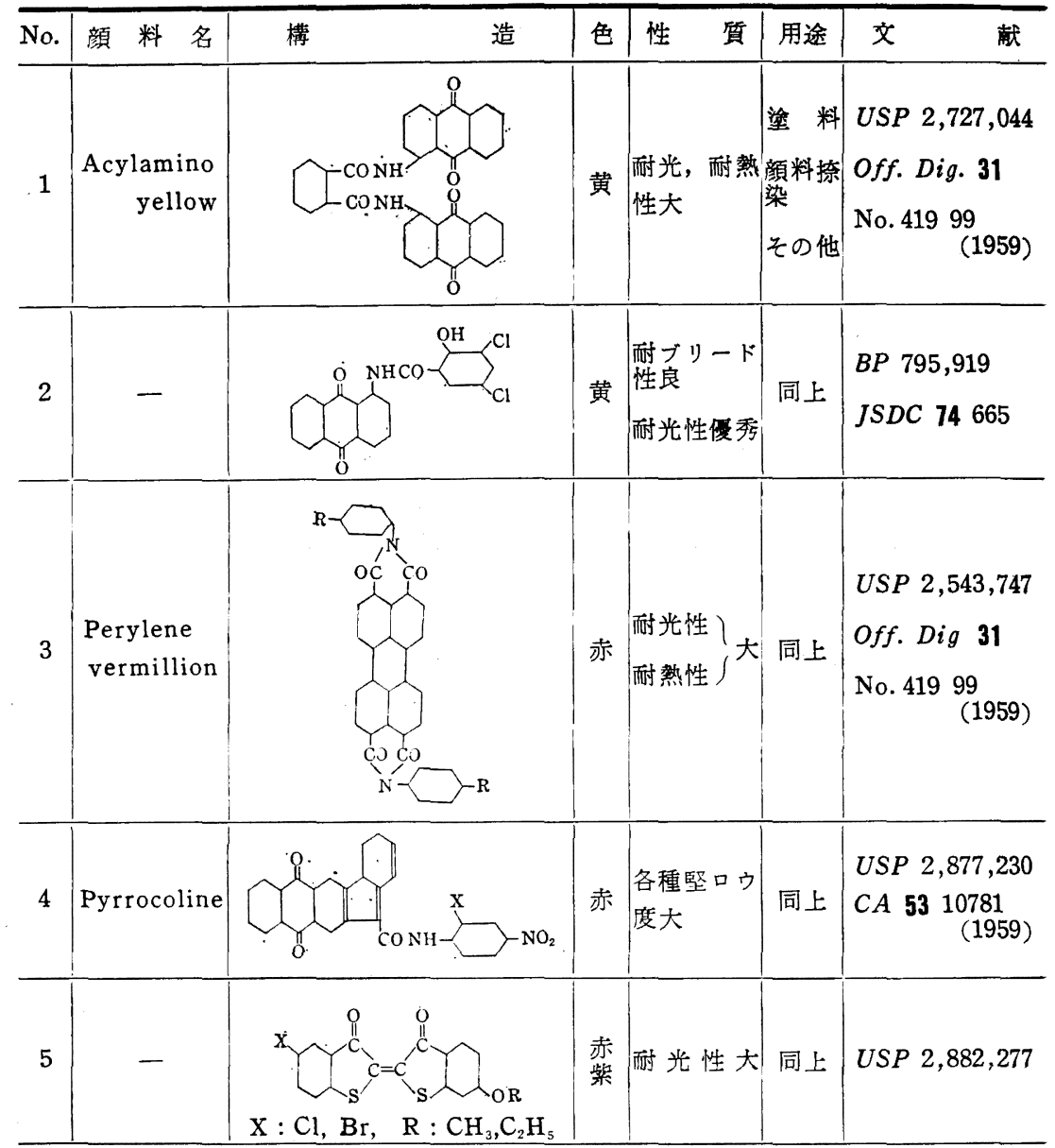

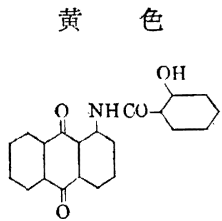

Anthrazen

Yellow $6 \mathrm{GL}$

(C. I. 60520)

最近スレン系顔料とし

ては新しいものはあまり

みられないが，その一例

を表 9 に示す。

この系属するいくつ かのものが同質多像であ

ることが知られる。

Warwicker は 10 種

類のアントラキノンバット染料について粉末法による $\mathrm{X}$ 線回折の測定を行い同質多像性を明らかにした ${ }^{76)} 。$

V. C. Vesce ${ }^{77}$ は Light Fast Colors としてつぎの ものを上けている。

Violet : Halogenated Thio Indigo ${ }^{78)}$,

Halogenated Isoviolanthrone,

Carbazole Dioxazine

Blue : Halogenated Indanthrone ${ }^{79}$, Phthalocyanine (Red Shade),

表 9 ス レン糸顔料 
何か御役に立てば本望に存するしだいである。

本稿の内容すべては当社橋爪清氏の調查, 弟作によっ たものであることを申上げてここに感謝の意を表しま す。

\section{文 献}

1) A Burawdy, J. Oil \& Colour Chem. Assoc. 35 303 307 (1952)

2) D. N Kendall, Proc. Indian Acad. Sci. $12 \mathrm{~A}$ 93 (1940)

3）赤外吸収スペクトル，第 4 集 p. 71 (南江堂)

4) 佐久間信二, 色材 28 [4]143 147（昭 30）

5）橋爪清，色材 31 [9] 373 380（昭 33）

6) 橋爪清，色材 32 [12〕 473 479（昭 34)

7) 平石文雄 5 , 印刷局研究所時報 5(9) 1 (昭 28)

8) USP 2,687,410 (1954)

9) L. S. Pratt, "The Chemistry and Physics of Organic Pigment" p. 27 (1947)

10) G. Bleisch, Farbe u. Lack 63341 (1957)

11) $B P 778,806,768,832$ (1957)

12) 特許公告 昭 34-2983

13) 有川俊一5, 有合化 1629 (1958)

14）橋爪清 5, 色材 33 10 13 (1960)

15) Ciba 社製品

16) Geigy 社製品

17) Höchst 社製品

18) V.C. Vesce, Official Digest 31 Dec. 1959 No. 419 part 2 p. 63

19）犬飼鑑ら, 色材 32 No.6 1 (昭 34)

20）橋爪清，未発表

21）同上, 同上

22) L. S. Pratt, "The Chemistry and Physics of Organic Pigment" p.130 (1947)

23）（針）(粒) は飽和溶液における不溶解分の結晶形 態を示す。

24) K. Venkataramann, "The Chemistry of Synthetic Dyes" p. 488 (1952)

25) USP 2,626,255

26) $B P$ 672,922, 672,923

27) USP 2,801,996 (1957), 2,396,327

28) 番匠吉衛 , 色材 32484 (昭 34)

29) Robertson, J. Chem. Soc. 615 (1935)

30) ibid. J., Chem. Soc. 1195 (1935)

31) " J. Chem. Soc. 219 (1937)

32) F. R Tarantino, American Ink maker Feb. 35 (1951)

33) D. N. Kendall, Proc. Indian Acad. Sci $12 \mathrm{~A}$ 93 (1940)

中村清: 赤外吸収スペクトル 第 4 集 p. 71 (南江 堂)

34) Brouillard, American Ink maker March 39 (1957)

35) USP 2,485,351

36) USP 2,615,026, 2,615,027, 2,618,642

37) 本稿ではアシッドペーステングで得られたものを $\beta$-型，ロバートソン型針状結晶のものを $\alpha$-型と
称す。

38) FIAT 1313 (PB 85172) p. 300

39) USP 2,770,629 (1956); BP 783,634

40) 酸, アルカリ洗いを行って得られた, アシッドペ ーステング前のものをCrude とよら゙ことKする。

41）銅フタロシアニンの針状結晶を $\alpha$-型, そのアシ ッドペーステングした物を $\beta$-型とよぶことにす る。

42) 橋爪清, 未発表

43) USP 2,910,482 (1959), 2,799,594 (1957), 2,8 16,045 (1957), 2,626,345

44) $B P 761,718$ (1957)

45) USP 2,885,957, 2,816,005 (1958)

46) $B P 781,239,804,031$

47) USP 2,476,950, 2,476,951, 2,615,027, 2,618, $642,2,615,026$

48) USP 2,327,472

49) USP $2,618,642$

50) USP $2,770,629$

51) USP 2,485,351, 2,615,026, 2,615,027, 2,618, 642

52) V. C. Vesce, Offcial Digest 31 No. 419 part 2 p. 121 (1959)

53) USP 2,761,868

54) H. T. Lacey, G. L. Roberts, “Paint \& Var. nish Production" April 33 38, 92 (1958)

55) 例 Heliogen Green GG. (C. I. 74120)

56) 例 Heliogen Green B (C. I. 74280)

57) General Dyestuff 弊品

58）橋爪清，未発表

59) $G P$ 945,782 (1958)

60) W. C. Drinkard, J. Am. Chem. Soc. No. 18 4795 (1959)

61) BP 801,488, J. Soc. Dyers Colourists. 74876 (1958)

62) C.S. Marvel 5 J. Am. Chem. Soc 801197 (1958)

63) 特公 昭 34-633

64) $B P 762,778$ (1956), 763,085

65) USP 2,845,420 (1958)

66) USP 2,843,498 (1958); J Soc. Dyers Colourists 75166 (1959)

67) Eckert, Seidel, J. $\operatorname{Pr} 210,338$ (1926)

68) Lesnianski; $C 1927$ I 3006

69) Ullmann, Maag, Ber. 391695

70) H. Liebermann, Ann. 518 245 259 (1935)

71) Dupont 社から Cinquasia $\operatorname{Red} Y, \operatorname{Red} B$, Violet $\mathrm{R}$ の商品名の下に市販されている。

72) American Ink maker 36 (No.6) 39 (1958), 36 (No.10) 45 (1958); USP 2,844,484, 2,844,48 $5,2,844,581$ (1958); USP 2,821,529 (1958), $2,821,541$ (1958)

73) USP 2,821,530 (1958)

74) $2,830,790$ (1958)

75）橋爪清, 未発表

76) J. O Warwicker, J. Textile Inst. 50 T 443 447 (1959) 
77) V. C. Vesce, Am. Ink maker Jau. $34 \sim 37$ (1958)

78) 例<smiles>CC(Cl)C1SC(=C2SC3CCC(Cl)CC3C2=O)C(=O)C1C</smiles>

Indo Red MV-6632 (C. I. 73310)

80)

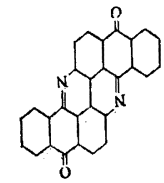

Indanthrene Yellow G

(C. I. 70600 )
79) 例

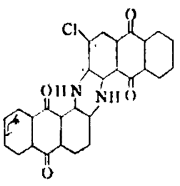

Indanthrene Blue $\mathrm{BC}$

(C. I. 69825)

81) 例

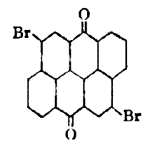

Indanthrene

Brilliant Orange RK

(C. I. 59300)
82) 例

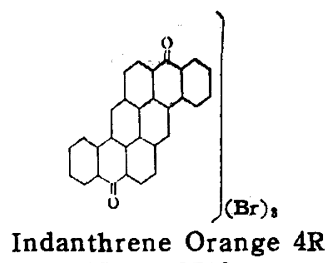

(C. I. 59710)

83) 例

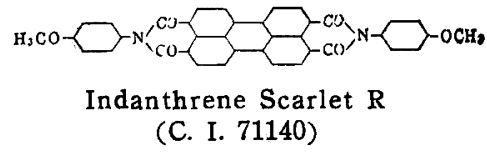

\section{「有機化合物合成法」}

\section{原稿募集についてのお知らせ}

かねてから当協会で編集, 発行いたして招ります「有機化合物合成法: 弥 巻を重ねるごとにますます好評を頂き今後な招一層内容を充実したものと 致し度く存じます。つきましては本書の原稿を下記により広く募集いたしま す。有機化合物の合成についてのデータを拓持ちのかたはこの際ふるってご 投稿ください。

はじめ化合物の名と, その合成方法の大要（反応式でもよい, 収率を入 れること）をハガキに書いて当協会内「有機化合物合成法」編集委員会あこ 扣送りください。重複をしらべたうえ原稿用紙を扣送りいたします。

\section{執筆についてのお願い}

1. ある特定の有機化合物をとりあげ，これを 1 項目としてその合成法をくわしく記載すること （具体的な執筆要項は「合成法」第 10 集もしくは 第 12 集の巻頭に記載されて抢りますからご参照 ください)。

2.とりあげるべき合成方法としては,なんら かの意味で特長をむっていること（たとえば収率 がよいこと、ひしょうに純粋なあのが得られるこ と, 操作がかんたんであること，あるいは原料が きわめて入手しやすいこと)。実験室でまちがい
なく、そのまま操作できることが確実ならば，既 刊の成書あるいは報告書にある方法をむとにし て，あるいは少し改良して，それをくわしく述べ てもさしつかえない。

3. 合成法にかぎらず，工業製品の実験室的な 精製法（たとえばキシンンの精製法あるいは天然 物の分離精製法でもさしつかえない。

4. すでと本書に採用されている項目は第12集 巻末に記載されてあります。 